\title{
PENGARUH PENGGUNAAN MEDIA FILTRASI TERHADAP KUALITAS AIR SUMUR GALI DI KELURAHAN TAMBAK REJO WARU KABUPATEN SIDOARJO
}

\author{
Usman Bapa Jenti**) dan Indah Nurhayati*)
}

\begin{abstract}
Abstrak
Tingginya tingkat kekeruhan dan kadar Fe dalam air dapat menyebabkan gangguan pada kesehatan. Oleh karena itu harus dilakukan pengolahan dengan filtrasi. Filtrasi digunakan untuk menurunkan kekeruhan dan kadar Fe dengan memanfaatkan media kerikil, pasir kwarsa dan karbon aktif.Tujuan penelitian ini adalah mengkaji tingkat kekeruhan dan kadar Fe sebelum dan sesudah difiltrasi dengan media kerikil, pasir kuarsa dan karbon aktif serta mengkaji pengaruh kombinasi media filtrasi terhadap penurunan kekeruhan dan Fe. Variabel bebas pada penelitian ini adalah kombinasi media filtrasi pada filter 1 menggunakan batu kerikil $20 \mathrm{~cm}$, pasir kwarsa $40 \mathrm{~cm}$, dan karbon aktif $20 \mathrm{~cm}$ sedangkan filter 2 menggunakan batu kerikil $20 \mathrm{~cm}$, pasir kwarsa $50 \mathrm{~cm}$ dan karbon aktif $10 \mathrm{~cm}$. Parameter yang diukur pada penelitian ini adalah kekeruhan dan kadar Fe. Reaktor filtrasi adalah pipa PVC ukuran 4 inchi dengan panjang 1 meter. Penelitian ini diperoleh hasil bahwa filter 1 setelah filtrasi selama 65 menit dapat menurunkan tingkat kekeruhan $75 \%$ dan kadar Fe 83 \% sedangkan pada filter 2 dapat menurunkan tingkat kekeruhan 87 \% dan kadar Fe $89 \%$. Setelah difiltrasi pada masing-masing filter dapat menurunkan tingkat kekeruhan dan kadar Fe dengan cukup baik namun penurunan tingkat kekeruhan dan kadar Fe pada filter 2 lebih bagus dari filter 1. Kesimpulan dari penelitian ini adalah Setelah difiltrasi dengan filter 1 selama 65 menit tingkat kekeruhan menjadi 9,80 NTU dan kadar Fe menjadi 7,10 mg/l sedangkan filter 2 tingkat kekeruhan menjadi 4,90 NTU dan kadar Fe menjadi 4,50 mg/l serta Filter 2 dengan menggunakan media kerikil $20 \mathrm{~cm}$, pasir kwarsa $50 \mathrm{~cm}$ dan karbon aktif $10 \mathrm{~cm}$ mendapakan hasil filtrasi yang lebih bagus daripada filter 1 dengan menggunakan media kerikil $20 \mathrm{~cm}$, pasir kwarsa $40 \mathrm{~cm}$ dan karbon aktif $20 \mathrm{~cm}$.
\end{abstract}

Kata Kunci : Media Filtrasi, Kekeruhan, Besi ( Fe ), Pasir Kwarsa, Kerikil, Karbon Aktif

\section{PENDAHULUAN}

Untuk mencukupi kebutuhan air dalam kebutuhan sehari-hari, sebagian besar masyarakat di Kelurahan Tambak Rejo menggunakan air sumur.Masyarakat di sekitarnya tidak tahu apakah air sumur tersebut layak digunakan untuk kebutuhan sehari-hari atau tidak. Oleh karena itu perlu ditinjau kembali mengenai kelayakan air sumur di Kelurahan Tambak Rejo.

Situasi dan kondisi yang kurang mendukung biasanya menyebabkan manusia terpaksa menggunakan air yang tidak memenuhi syarat untuk kehidupannya. Untuk dapat memberikan gambaran tentang sifat-sifat air, maka kita harus mengetahui kandungan zat yang terdapat pada air. Berdasarkan standart baku mutu air bersih menurutPeraturan Menteri Kesehatan Republik Indonesia Nomor : 416 /MENKES / PER / IX/ 1990 tentang syarat kualitas air bersih, zat yang penting diperiksa dalam air terutama secara kimiawi adalah Besi, Calcium, Magnesium, Arsen, Flourida, Clorida, Sulfat, Nitrat, Kesadahan. Selain itu air tidak boleh mengandung bahan berbahaya lainnya seperti logam berat dan bakteri yang membahayakan.

Air keruh adalah air yang mengandung bahan padat dan mencemari lingkungan sehingga dapat menyababkan gangguan pada kesehatan. Air keruh juga merupakan air yang tercemar dan kotor, sehingga akan dapat menyababkan terjangkit penyakit menular dan gangguan kesehatan. Kekeruhan belum tentu dari sifat air yang membahayakan, tetapi masyarakat pada umumnya berpendapat bahwa air keruh adalah air yang tercemar dan kotor, sehingga timbul kekhawatiran akan terjangkit penyakit-penyakit menular dan gangguan kesehatan lainnya.Air yang sangat keruh akan mempercepat terjadinya penyumbatan pada celah-celah media penyaring, sehingga menghasilkan daya kerja penyaringan yang kurang memuaskan.

\footnotetext{
**) Mahasiswa Teknik Lingkungan

*) Dosen Teknik Lingkungan Universitas PGRI Adi Buana Surabaya
} 
Pemakaian air yang derajat kekeruhannya melebihi ambang batas yang diperbolehkan akan dapat menyebabkan efek yang tidak baik terhadap kesehatan, terutama karena kekeruhan yang tinggi merupakan media yang cukup baik bagi perkembangan mikroorganisme serta dapat melindunginya dari pengaruh berbagai ancaman, sehingga efek dari desinfektan mengharapkan mikroorganisme berada di permukaan partikel-partikel penyebab kekeruhan, oleh sebab itu pada proses desinfeksi diperlukan pengadukan dan waktu kontak yang optimum.

Zat besi (Fe) adalah merupakan suatu komponen dari berbagai enzim yang mempengaruhi seluruh reaksi kimia yang penting di dalam tubuh meskipun sukar diserap ( $10-15 \%)$. Besi juga merupakan komponen dari hemoglobin yaitu sekitar $75 \%$, yang memungkinkan sel darah merah membawa oksigen dan mengantarkannya ke jaringan tubuh.

Kelebihan zat besi (Fe) bisa menyebabkan keracunan dimana terjadi muntah, kerusakan usus, penuaan dini hingga kematian mendadak, mudah marah, radang sendi, cacat lahir, gusi berdarah, kanker, sirosis ginjal, diabetes, diare, pusing, mudah lelah, kulit kehitam - hitaman, sakit kepala, gagal hati, hepatitis, mudah emosi, hiperaktif, hipertensi, infeksi, insomnia, sakit liver, masalah mental, rasa logam di mulut, mudah gelisah dan iritasi, parkinson, rematik, sikoprenia, sariawan perut, sicklecell anemia, keras kepala, strabismus, gangguan penyerapan vitamin dan mineral, serta hemokromatis.

Filtrasi merupakan salah satu pengolahan air secara fisik. Filtrasi adalah proses pemisahan solid-liquid dengan cara melewatkan liquid melalui media berpori atau bahan-bahan untuk menyisihkan atau menghilangkan sebanyak-banyaknya butiran-butiran halus zat padat tersuspensi dari liquida.

Pasir kwarsa merupakan batuan sedimen yang umumnya disusun oleh mineral kwarsa, sering berlapis, dari butiran halus hingga kasar. Kegunaan pasir kwarsauntuk menghilangkan kandungan lumpur atau tanah dan sedimen pada air minum atau air tanah. Karbon aktif adalah sejenis adsorbsen ( penyerap ). Berwarna hitam berbentuk granula, bulat, palet atau bubuk. Karbon aktif dipakai dalam proses pemurnian udara, gas, larutan atau cairan, dalam proses recovery. Karbon aktif berfungsi untuk menghilangkan kandungan zat organik, bau, rasa yang kurang sedap, polutan mikro lainnya.

Batu Kerikil pada dasarnya adalah batu besar, tetapi hancur karena reaksi alam atau biasa yang disebut pelapukan yang terjadi karena perubahan suhu alam yang mendadak atau lumut-lumutan. Bisa juga hancur diinjak oleh orang-orang yang berberat badan tidak ideal (obesitas). Atau tertimpa oleh barang-barang yang berberat besar.Kerikil adalah agregat kasar yang mengandung mineral seperti batu, karena pengerasan dananyaknya kuarsa. Warnaya kuning hingga abu-abu, dan sifatnya tahan terhadap ouaca, keras.

Tujuan penelitian ini adalah : (1) Untuk mengkaji tingkat kekeruhan dan kadar Fe pada air sumur sebelum dan sesudah difiltrasi dengan menggunakan media kerikil, pasir kwarsadan karbon aktif. (2) Mengkaji pengaruh penggunaan media filtrasi terhadap penurunan $\mathrm{Fe}$ dan kekeruhan

Manfaat dari penelitian ini adalah : ( 1) Menambah pengetahuan dan wawasan bagi penulis mengenai proses penurunan kekeruhan dan kadar $\mathrm{Fe}$ air sumur dengan menggunakan pasir kwarsa dan karbon aktif. (2) Bagi masyarakat kelurahan Tambak Rejo sebagai salah satu alternatif yang digunakan untuk menurunkan tingkat kekeruhan dan kadar $\mathrm{Fe}$ air sumur. (3) Informasi untuk pemerintah dalam mengambil keputusan tentang penyediaan air bersih yang berkualitas kepada masyarakat. (4) Dapat digunakan sebagai pedoman untuk penelitian lebih lanjut.

\section{METODE PENELITIAN}

Populasi dalam penelitian ini adalah air sumur gali yang biasa digunakan oleh masyarakat Kelurahan Tambak Rejo.Sampel Penelitiannya adalah Air sumur gali di rumah ibu Sumarni di kelurahan Tambak Rejo RT03/RW02 No.18 digunakan sebagai sampel dalam penelitian ini.

Media filtrasi yang digunakan adalah media kerikil dengan diameter $20-35 \mathrm{~mm}$, media pasir kwarsa dengan diameter 0,2 $0,5 \mathrm{~mm}$ serta media karbon aktif dengan bentuk granula berdiameter $0,2-0,5 \mathrm{~mm}$. Penggunaan media filtrasi dengan Filter 1 menggunakan batu kerikil $20 \mathrm{~cm}$, pasirkwarsa $40 \mathrm{~cm}$ dan karbon aktif $20 \mathrm{~cm}$ sedangkan Fikter 2 menggunakan batu kerikil $20 \mathrm{~cm}$, pasir kwarsa $50 \mathrm{~cm}$ karbon aktif $10 \mathrm{~cm}$. Variabel bebas dalam penelitian ini adalah kommbinasi media filtrasi sedangkan Variabel terikat dalam penelitian ini adalah Kualitas air sumur gali 


\section{Waktu dan Tempat}

( 1 ) Tempat penelitian dilakukan di kelurahan Tambak Rejo, analisis $\mathrm{Fe}$ dan kekeruhan dilakukan di Balai Penelitian dan Konsultasi Industri (BPKI) Surabaya - Jawa Timur, JI. Ketintang Baru XVII No. 14.

( 2 ) Alat dan bahan : ( a ) Pompa air . (b ) Reaktor filtrasi dari Pipa PVC 4 Inchi. (c) Alat aerasi dari ember plastik di lubangi. ( d ) Kerikil. (e ) Pasir Kwarsa. ( $f$ ) Arang Tempurung.

\section{Langkah - Langkah Pelaksaan Penelitian}

\section{(1) Pelaksanaan Penelitian}

( a )Air baku dari air sumur gali dipompa ke pipa aerasi. Setelah dari pipa aerasi air ditampung di bak sedimentasi.Kran bak sedimentasi dibuka sehingga air mengalir dari bak penampung ke pengatur debit. Dari pengatur debit dialirkan kedua bak filtrasi dengan jenis ketebalan media yang berbeda dan dialirkan secara bersamaan. ( b ) Pengukuran debit aliran pada proses filtrasi dilakukan dengan cara mengalirkan air dari pengatur debit ke reaktor dengan bersamaan. Bila air sudah terisi kran outlet dibuka. Menyediakan gelas ukur dengan ukuran 1 liter untuk menampung air outlet.Stopwatch dinyalakan bersamaan dengan air outlet mengisi gelas ukur. Stopwath dimatikan pada saat air sudah terisi 1 liter. Kemudian dihitung waktu yang diperlukan untuk menampung air tersebut. Pengukuran debit dilakukan sampai diperoleh hasil yang sama dan membiarkan sementara waktu air mengalir sampai alirannya stabil. 1 liter air di isi dalam waktu 1 menit jadi 1000 liter dibagi 60 detik ( 16,7 $\mathrm{ml} /$ det ). ( c ) Air yang keluar dari outlet ditampung untuk dianalisis kadar $\mathrm{Fe}$ dan kekeruhan. ( d ) Pengambilan sampel pada sampel dilakukan pada menit ke 20, menit ke 35 , menit ke 50, menit ke 65 dan
Memberikan label pada masing-masing sampel. ( e ) Selanjutnya air sampel tersebut dibawa ke laboratorium Balai Penelitian dan Konsultasi Industri ( BPKI) untuk dilakukan analisa kekeruhan dan kadar Fe.

\section{Metode Analisa Data}

Data yang diperoleh diolah sesuai dengan tujuan penelitian yang telah dirumuskan untuk mendapatkan kesimpulan. Metode yang disajikan dalam bentuk tabel dan grafik.

\section{HASIL PENELITIAN}

Kadar awal air sumur gali di kelurahan Tambak Rejo RT 03 / RW 02 No 18 untuk parameter kekeruhan $=38,50$ NTU dan kadar $\mathrm{Fe}=41,5 \mathrm{mg} / \mathrm{l}$. Dari hasil tersebut menunjukan bahwa air sumur tersebut, kekeruhan dan kadar $\mathrm{Fe}$ diatas baku mutu air bersih sesuai dengan PERMENKES No 416 / IX / 1990, oleh karena itu perlu ada treatment untuk menurunkan kadar $\mathrm{Fe}$ dan kekeruhan. Sebelum difiltrasi air sumur diaerasi terlebih dahulu mengalirkan air ke pipa aerasi, tujuannya untuk membantu menurunkan $\mathrm{Fe}$. Kadar Fe setelah diaerasi adalah $26,4 \mathrm{Mg} / \mathrm{l}$. Dari hasil aerasi kandungan $\mathrm{Fe}$, menunjukan terjadinya penurunan namun belum memenuhi standar baku mutu air bersih sehingga dilakukan pengolahan lanjut dengan filtrasi.

\section{PEMBAHASAN}

Dari hasil penelitian tingkat kekeruhan dan kadar $\mathrm{Fe}$ sumur gali di kelurahan Tambak Rejo,diketahui bahwa tingkat kekeruhan dan kadar $\mathrm{Fe}$ setelah filtrasi mengalami penurunan.

Prosentase penurunan tingkat kekeruhan sumur gali di kelurahan Tambak Rejo dapat dilihat pada tabel. 1 di bawah ini.

Tabel.1Penurunan Tingkat Kekeruhandan Kadar FeDengan Filter 1

\begin{tabular}{|c|c|c|c|c|c|c|c|c|}
\hline \multirow[t]{2}{*}{ Waktu } & \multicolumn{2}{|c|}{$\begin{array}{l}\text { Tingkat } \\
\text { Kekeruhan } \\
\text { (NTU) }\end{array}$} & \multirow[t]{2}{*}{$\begin{array}{c}\text { Penurunan } \\
\text { (NTU) }\end{array}$} & \multirow[t]{2}{*}{ Ef (\%) } & \multicolumn{2}{|c|}{$\begin{array}{c}\text { Kadar Fe } \\
(\text { ppm) }\end{array}$} & \multirow{2}{*}{$\begin{array}{c}\text { Penuruna } \\
\text { n } \\
(\mathrm{ppm})\end{array}$} & \multirow[t]{2}{*}{ Ef $(\%)$} \\
\hline & Awal & Akhir & & & Awal & Akhir & & \\
\hline Menit ke 20 & 38,5 & 24,5 & 14 & $36,36 \%$ & 41,50 & 20,50 & 21,00 & $50,60 \%$ \\
\hline Menit ke 35 & 38,5 & 18,3 & 22,2 & $52,47 \%$ & 41,50 & 14,60 & 26,90 & $64,82 \%$ \\
\hline Menit ke 50 & 38,5 & 12,5 & 26 & $67,53 \%$ & 41,50 & 9,20 & 32,30 & $77,83 \%$ \\
\hline Menit ke 65 & 38,5 & 9,8 & 28,7 & $74,55 \%$ & 41,50 & 7,10 & 34,40 & $82,89 \%$ \\
\hline
\end{tabular}


Dari tabel.1, dapat dilihat bahwa setelah di filtrasi dengan filter 1 selama 65 menittingkat kekeruhan yang semula 38,5 NTU turun menjadi 9,8 NTU sedangkan kadar $\mathrm{Fe}$ yang semula 41, $5 \mathrm{mg} / \mathrm{l}$ turun menjadi 7,1 mg/l. Jika dibandingkan dengan KEPMENKES No. 416 / IX / 1990, ternyata air sumur gali di kelurahan Tambak Rejo setelah di filtrasi dengan filter 1 kekeruhan sudah memenuhi baku mutu air bersih sedangkan kadar Fe belum memenuhi baku mutu air bersih, sehingga masih perlu dilakukan filtrasi dalam waktu yang lebih lama sehingga diperoleh air dengan kadar Fe yang memenuhi baku mutu air bersih.

Prosentase penurunan tingkat kekeruhan sumur gali di kelurahan Tambak Rejo dapat dilihat pada tabel. 2.

Tabel.2 Penurunan Tingkat Kekeruhandan Kadar Fe Dengan Filter 2

\begin{tabular}{|c|c|c|c|c|c|c|c|c|}
\hline \multirow[t]{2}{*}{ Waktu } & \multicolumn{2}{|c|}{$\begin{array}{l}\text { Tingkat } \\
\text { Kekeruhan } \\
\text { (NTU) }\end{array}$} & \multirow{2}{*}{$\begin{array}{c}\text { Penuruna } \\
n \\
\text { (NTU) }\end{array}$} & \multirow[t]{2}{*}{ Ef $(\%)$} & \multicolumn{2}{|c|}{$\begin{array}{c}\text { Kadar Fe } \\
\text { ( ppm) }\end{array}$} & \multirow[t]{2}{*}{$\begin{array}{l}\text { Penurunan } \\
(\mathrm{ppm})\end{array}$} & \multirow[t]{2}{*}{ Ef $(\%)$} \\
\hline & Awal & Akhir & & & Awal & Akhir & & \\
\hline Menit ke 20 & 38,50 & 21,50 & 17,00 & $44,76 \%$ & 41,50 & 17,40 & 24,10 & $58,07 \%$ \\
\hline Menit ke 35 & 38,50 & 16,30 & 22,20 & $57,66 \%$ & 41,50 & 10,10 & 31,40 & $75,66 \%$ \\
\hline Menit ke 50 & 38,50 & 9,40 & 29,10 & $75,58 \%$ & 41,50 & 4,90 & 36,60 & $88,19 \%$ \\
\hline Menit ke 65 & 38,50 & 4,90 & 33,60 & $87,27 \%$ & 41,50 & 4,50 & 37,00 & $89,16 \%$ \\
\hline
\end{tabular}

Dari tabel.2, dapat dilihat bahwa setelah di filtrasi dengan filter 2 selama 65 menit tingkat kekeruhan yang semula 38,5 NTU turun menjadi 4,9 NTU sedangkan kadar Fe yang semula 41,5 NTU turun menjadi 4,5 NTU. Jika dibandingkan dengan KEPMENKES No.416 / IX / 1990, ternyata air sumur gali Tambak Rejo setelah di filtrasi dengan filter 2 tingkat kekeruhan sudah memenuhi baku mutu air bersih sedangkan kadar Fe belum memenuhi baku mutu air bersih.

Berikut adalah prosentase penurunan tingkat kekeruhan dan kadar $\mathrm{Fe}$ sumur gali di kelurahan Tambak Rejo pada filtrasi I dan filtrasi II :

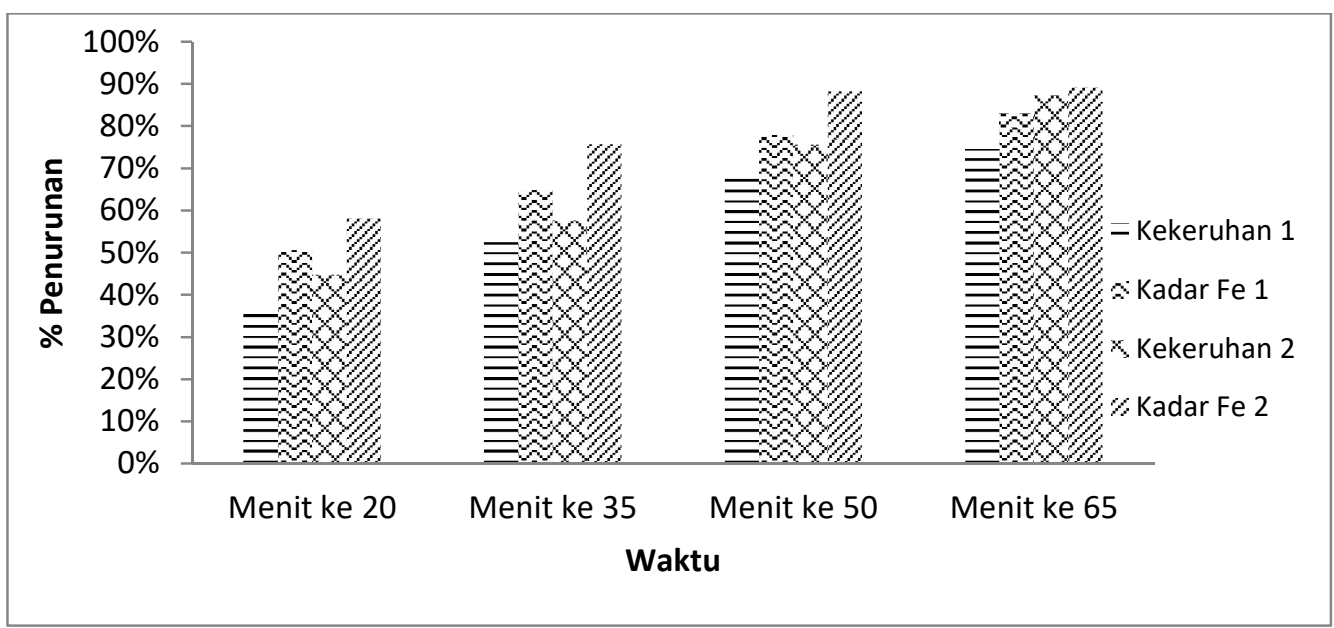

Gambar 1 : Prosentase Penurunan Filter 1 dan 2

Dari gambar 1 diatas menunjukan bahwa penurunan kadar Fe dan kekeruhan pada filter 1 dan 2 mulai dari menit ke 20 sampai menit ke 65 semakin lama waktu filtrasi semakin tinggi tingkat penurunannya.
Dari gambar 1 menunjukan bahwa tingkat penurunan $\mathrm{Fe}$ dan kekeruhan pada filter 2 lebih tinggi daripadafilter 1 , namun belum memenuhi baku mutu air bersih. Hal ini dikarenakan filter 2 dengan komposisi media 
kerikil $20 \mathrm{~cm}$, pasirkwarsa $50 \mathrm{~cm}$ dan karbon aktif $10 \mathrm{~cm}$ sedangkan filter 1 dengan komposisi media kerikil $20 \mathrm{~cm}$, pasir kwarsa $40 \mathrm{~cm}$ dan karbon aktif $20 \mathrm{~cm}$. Tinggi media pasir kwarsa pada filter 2 lebih tinggi daripada filter 1. Hal ini dikarenakan Pasir kwarsa digunakan dalam proses pengolahan air untuk menyerap sekaligus menyaring kandungan lumpur atau tanah dan sedimen pada air minum atau air tanahSetelah dibandingkan dengan KEPMENKES No 416/IX/1990 tenyata hasil dari filter 1 dan 2 untuk parameter Fe belum memenuhi baku mutu air bersih sedangkan parameter kekeruhan sudah memenuhi baku mutu air bersih

\section{KESIMPULAN DAN SARAN}

Kesimpulan

Dari hasil penelitian terhadap tingkat kekeruhan dan kadar Fe pada air sumur gali dikelurahan Tambak Rejo sebelum dan setelah proses filtrasi dapat disimpulkan sebagai berikut : (1) Uji tingkat kekeruhan dan kadar Fe sebelum difiltrasi adalah 38,50 NTU dan 41,50 mg/l. ( 2 ) Setelah difilltrasi dengan filter 1 selama 65 menit tingkat kekeruhan menjadi 9,80 NTU dan kadar Fe menjadi $7,10 \mathrm{mg} / \mathrm{l}$ sedangkan filter 2 tingkat kekeruhan menjadi 4,90 NTU dan kadar $\mathrm{Fe}$ menjadi $4,50 \mathrm{mg} / \mathrm{l}$.( 3 ) Filter 2 dengan menggunakan media kerikil $20 \mathrm{~cm}$, pasir kwarsa $50 \mathrm{~cm}$ dan karbon aktif $10 \mathrm{~cm}$ mendapakan hasil filtrasi yang lebih bagus daripada filter 1 dengan menggunakan media keirikil $20 \mathrm{~cm}$, pasir kwarsa $40 \mathrm{~cm}$ dan karbon aktif $20 \mathrm{~cm}$.

Saran

( 1 ) Kadar Fe pada penelitian ini masih diatas baku mutu air bersih sehingga diharapkan ada penelitian lanjutan tentang penurunan kadar Fe dan kekeruhan pada air sumur gali.( 2 ) Sebaiknya waktu penyaringan yang dibutuhkan dalam proses filtrasi lebih ( diatas 65 menit ) sehingga mendapatkan hasil yang lebih maksimal.

\section{DAFTAR PUSTAKA}

Alaetrs. G, Sri Sumentri, Santika, 1987. "Metode Analisis Air ", Usaha Nasional Surabaya

Asmadi, Khayan, Heru Subarsi Kasjono, 2011, " Teknologi Pengolahan Air Minum ". Goysen Publishing, Yogyakarta.

Aswar Asrul, 1996, " Pengantar Ilmu Kesehatan Lingkungan ". Jakarta, Mutiara Sumber Widya

Badan standarisasi Nasional, 2008. SNI-3981, Perencanaan Instalasi Saringan Pasir Lambat

Depertemen Kesehatan RI, Peraturan Menteri Kesehatan RI Nomor :416/MENKES/PER/IX/1990, tentang syarat-syarat dan pengawasan kualitas air bersih.

Fety Kumalasari, Yogi Satoto, 2011. "Teknik Praktis Mengolah Air Kotor Menjadi Air Bersih Hingga Layak Diminum ", Laskar Aksara, Bandung.

Kusnaedi, 2010, Mengolah Air Gambut dan Air Kotor untuk Air Minum, Jakarta Penebar Swadaya

Notoatmodjo,S, 1993. Metodologi Penelitian Kesihatan, Rineka Cipta, Jakarta.

Pambi, R.P. varonika, 2009 "Penurunan Tingkat Kekeruhan Dan Kesadahan Pada Air Tanah Dangkal Dengan Filtrasi “, Tugas Akhir Universitas PGRI Adi Buana Surabaya.

Sanropie, Djoko dan Mardjono, 1984.Penyediaan Air Bersih, Depkes RI, Jakarta.

Surachman, Winarno, 1990. "Pengertian Penelitian IImiah ",PT.Pustaka Binaman Pressindo. Bandung

Sutrisno, Joko, 2006. Satuan Operasi. Universitas PGRI Adi Buana Surabaya 